\title{
Aşırı İş Yükü Algısının İşten Ayrılma Niyeti Üzerine Etkisinde Sürekli Kaygının Aracılık Rolü
} (Araştırma Makalesi)

The Mediating Role of Trait Anxiety in the Effects of Work Overload on Turnover Intention

Doi: 10.29023/alanyaakademik.558557

Tahsin AKÇAKANAT

Dr. Öğr. Üyesi, Süleyman Demirel Üniversitesi, İ̈BF, Işsletme Bölümü tahsinakcakanat@sdu.edu.tr

Orcid No: 0000-0001-9414-6868

\section{Hasan Hüseyin UZUNBACAK}

Dr. Öğr. Üyesi, Süleyman Demirel Üniversitesi, İBF, Işsletme Bölümü hasanuzunbacak@sdu.edu.tr

Orcid No: 0000-0002-3297-1659

Bu makaleye atıfta bulunmak için: Akçakanat, T., \& Uzunbacak, H.H. (2019). Aşırı İs Yükü Algısının İsten Ayrılma Niyeti Üzerine Etkisinde Sürekli Kaygının Aracılık Rolü. Alanya Akademik Bakış, 3(3), Sayfa No. 215-230.

\author{
Anahtar kelimeler: \\ Sürekli Kaygl, \\ Aşırı İş Yükü, \\ Issten Ayrlma Niyeti, \\ Aracılık Rolü \\ Makale Geliş Tarihi: \\ 27.04.2019 \\ Kabul Tarihi: \\ 13.05.2019
}

\section{ÖZET}

Bu çalışma, aşırı iş yükü algısı ile işten ayrılma niyeti arasındaki ilişkide sürekli kaygının rolünü tespit etmek amacıyla yapılmıştır. Araştırmanın verileri, bir sigara işletmesinin Isparta il genelinde görev yapan satı̧̧ elemanlarından toplanmıştır. Bu kapsamda, 182 saha satış elemanından kolayda örneklem yöntemiyle elde edilen veriler, bootstrap regresyon analizi kullanılarak aracılık analizine tabi tutulmuştur. Elde edilen bulgulara göre, aşırı iş yükü algısı ile işten ayrılma niyeti ilişkisinde, sürekli kaygının aracılık rolü oynadığı tespit edilmiştir. Ulaşılan bulgular literatür doğrultusunda tartışılmış ve gelecek çalışmalar için önerilerde bulunulmuştur.

\section{ABSTRACT}

This study was carried out to determine the role of trait anxiety in the relationship between the work overload perception and turnover intention. The data of the study was collected from the salespersons of Isparta province. In this context, the data obtained from 182 salespersons with convenienve sampling method were subjected to mediation analysis using bootstrap regression analysis. According to the findings, it was found that trait anxiety plays an mediating role in the relation of work overload perception and turnover intention. The findings were discussed in the light of the literature and recommendations were made for future studies. 


\section{GİRIŞ}

İşletmelerin temel amaçları arasında sayılan karlılık ve süreklilik, günümüz işletmeleri için oldukça zorlu bir süreçtir. Bu süreçte işletmeler bir taraftan rekabet ederek, diğer taraftan kendini sürekli olarak geliştirerek, işletme genelinde en uygun stratejileri uygulamak durumundadır. $\mathrm{Bu}$ amaçla, kar marjını yükseltmenin, verimliliği ve performansı artırmanın, bunu yaparken de kaliteyi ihmal etmemenin ve işgücünden maksimum düzeyde yararlanmanın yolunu aramaktadırlar.

İşgücünden maksimum derecede yararlanabilmek için kimi zaman çalışanların bilgi ve tecrübe düzeyleri, kapasiteleri göz ardı edilerek, işletmenin beklentileri artmaktadır. Ancak, bu beklentiler, çalışanları stres yaşamasına ve iş yükünün ağırlaşmasına neden olarak, bireysel ve örgütsel olumsuzlukları ortaya çıkarmaktadır. $\mathrm{Bu}$ olumsuzlukların başında, tükenme, mutsuzluk, bağlılıkta ve tatminde azalma, performansta beklentileri karşılayamama gelmektedir.

İş performansını olumsuz olarak etkileyen iş stresi ve stresin ortaya çıkardığı kaygı, iş dünyasında önemli bir sorun olarak görülmektedir. Günümüzün rekabetçi ortamında, iş sahiplerinin ve müşterilerinin artan talep ve beklentilerinin ortaya çıkardığı aşırı iş yükü de stres kaynaklarından birisi olarak tanımlanmaktadır. İşle ilgili stresin yüksek olması, çalışanların işyeri mutluluğunu ve işten duyduğu tatmini etkileyerek, işletmeler açısından bir başka önemli sorun olan işgücü devir oranını artırabilmektedir. Bununla birlikte, teknolojinin ve internet kullanımının yaygınlaşması, ürün ve hizmetlerde farklılaşmanın yaşanması, rekabet ve pazarlama stratejilerinin sürekli değişimi özellikle satış elemanları üzerinde aşırı iş yükü kaynaklı stres ve kaygının oluşmasına neden olmaktadır (Jones vd., 2000).

Bu açıklamaların ışığında çalışmada, satış elemanlarının aşırı iş yükü algıları, kaygı düzeyleri ve işten ayrılma niyetleri arasındaki ilişkiler ele alınmıştır. Ayrıca aşırı iş yükü ile işten ayrılma niyeti ilişkisinde, sürekli kaygı düzeyinin rolü de çalışma kapsamında araştırılmıştır.

\section{KAVRAMSAL ÇERÇEVE}

İşten ayrılma niyeti, çalışanların halen çalıştıkları işyerinden ayrılma isteklerine ilişkin zihinsel ve davranışsal niyet olarak tanımlanmıştır (Tett ve Meyer, 1993: 262). Çalışanların işten ayrılma niyeti, yakın gelecekte, çalıştıkları işlerinden ayrılma ve yeni bir iş bulma isteklerini de yansıtmaktadır (Pradana ve Salehuddin, 2015: 110). İşten ayrılma davranışının öncülü olarak kabul edilen işten ayrılma niyeti, işe karşı tutumu ile işten ayrılma veya ayrılmama yönündeki bilinçli ve temkinli bir karar veya niyet olarak değerlendirilmektedir (Jacobs ve Roodt, 2011). Bu niyeti taşıyan çalışan, kafasını ve enerjisini yeni iş bulma için harcayacağından işini savsaklama eğilimi içerisinde olabilir (Vigoda, 2000: 332). Bu açıdan örgütlerin, ciddiyetle bu konu üzerinde durmaları ve gerekli önlemleri almaları önem arzetmektedir.

İş yaşamında işi bırakma davranışı, işten soğuma ve işten ayrılma niyeti olarak incelenmektedir. Çalışanın, işinin gereği olarak elde ettiği rolleri devam ettiği halde, işle ilgili yaşadığı olumsuzluklar sebebiyle, rollerinin gereklerini tam olarak yerine getirmemesi işten soğuma olarak ele alınmaktadır. İşten ayrılma niyeti, çalışanın işten uygun bir firsat bulduğunda hemen işten ayrılabileceğini ifade eder (Ünlüsoy Dinçer, 2010: 49). Buradan yola çıkarak işten ayrılma niyeti, çalışanın iş koşullarından memnun olmaması sebebiyle işini daha 
fazla yürütmek istememesi ve işi bırakma çabası olarak ifade edilmektedir (Hanisch ve Hulin, 1990: 64; Rusbelt vd., 1998: 604).

İşten ayrılma niyeti, “Akla Dayalı Davranış Teorisi”" çerçevesinde ele alınmaktadır. Teoriye göre, birey herhangi bir konuda karar alırken karmaşık bir süreçle hareket etmektedir. Bu süreç, tutumlar ve sübjektif normlara dayanmaktadır. Bireyin algılarının tutumları ortaya çıkaracağı, sosyal baskıların sonucunda ortaya çıkan davranışın ise sübjektif normların dayanak noktası olduğunu ifade eden teori, bu faktörlerden birinin veya ikisinin bireyin karşılaştığı herhangi bir durum karşısında niyetin ve tepkinin oluşmasına neden olduğunu savunmaktadır (Ajzen ve Fishbein, 1975). Bir başka ifadeyle, Akla Dayalı Davranış Teorisi, algılar ve davranışlar arasında tutumların rolü üzerinde durarak, davranışların ortaya çıkabilmesi için bireylerin algılarına ve tutumlarına ihtiyaç olduğunu vurgulamaktadır (Yıldız, 2016: 89). Bu bağlamda, işten ayrılma niyetini etkileyen pek çok neden olabilmektedir. Bu nedenler, yaş, cinsiyet, medeni durum, eğitim, sağllk durumu gibi kişisel faktörler, işletmenin kuruluş yeri, çalışma koşulları, yönetim uygulamaları, ödül ve ücret sistemi gibi örgütsel faktörler, ekonomik ve toplumsal şartlar, teknolojik ilerleme, işgücü piyasası gibi çevresel faktörler başlıkları altında sınıflandırılabilmektedir (Akdeniz, 2018).

İşten ayrılma niyetini ortaya çıkaran ve örgütsel faktörler arasında sayılan değişkenlerden birisi de aşırı iş yüküdür. Aşırı iş yükü, birim zamanda yapılması gereken işin, çalışanları baskı altına almasıdır (Greenberg, 1995: 12). Yapılan iş sebebiyle, çalışanın stres yaşamasına sebep olan faktörler arasında sayılan (Gümüştekin ve Öztemiz, 2005: 274) aşırı iş yükü, çalışanın yapmak zorunda olduğu işin miktarının fazlalığından ve zaman baskısından kaynaklanan, bireysel ve örgütsel olumsuz çıktılara sebep olan duygu olarak ifade edilmektedir (Aycan ve Yavuz, 2007).

Bireyler, kendilerine yüklenen görevlerin belirgin olmaması, işin bitirilmesi için yeterli sürenin tanınmaması, yönetici desteğinin yeterli düzeyde olmaması, yetersiz eğitim faaliyetleri hakkındaki yargıları sebebiyle aşırı iş yükü algısına kapılabilmekte ve bu durum işler üzerinde olumsuz etkilere neden olabilmektedir (Understanding ergonomics at work, 2013: 2-3).

Özkalp ve Kırel (2005: 435) aşırı iş yükünü, çalışanın yapması gereken çok sayıda iş olması anlamına gelen niceliksel ve çalışanın yaptığı işin bireysel beceri ve bilgi düzeyini aştığ1 halde yapması olarak ifade edilen niteliksel iş yükü olarak iki boyutta ele almıştır. Bununla birlikte aşırı iş yükü algısı, iş yapanın veya işin ve organizasyonun özelliklerinden kaynaklanabileceği gibi, yasa ve kurallardan da kaynaklanabilmektedir (Korkmaz, 2012: 24).

Aşırı iş yükünün, tükenmişlik (Portoghese vd., 2014; Bolat, 2011), örgütsel destek (Ilies vd., 2010), iş tatmini (Swartz, 1999), iş-aile çatışması (Yıldırım ve Aycan, 2008), çalışma yaşam kalitesi (Lai vd., 2012), yönetici desteği (Hetty van Emmerik vd., 2009) ve örgütsel bağlılık (Duxbury ve Halinski, 2014; Gökkaya, 2014) olmak üzere birçok değişkenle ilişkisi incelenmiştir.

Yazında, aşırı iş yükünün, bu araştırmanın da değişkenlerinden birisi olan işten ayrılma niyetinin öncülü olduğunu ortaya koyan araştırmalara rastlamak mümkündür. Nitekim, Duxbury ve Halinski, (2014: 670) işten ayrılma niyetinin ortaya çıkmasında etkisi olan temel değişkenlerden birisinin de iş yükü olduğunu ifade etmiştir. Zeytinoğlu ve arkadaşları (2007) tarafından gerçekleştirilen bir diğer araştırmada da iş yükünün artmasının işten ayrılma niyetini artıracağı tespit edilmiştir. Bununla birlikte aşırı iş yükünün işten ayrılma niyetini 
pozitif etkilediğine ilişkin bulgulara, başkaca araştırmaların sonuçlarında da ulaşılmıştır (Altay ve Turunç, 2018; Iverson ve Deery, 1997; Qureshi vd., 2013; Lee, 2011; Sümer ve Van de Ven, 2007). Bu kapsamda, araştırmanın ilk hipotezi aşağıdaki şekilde oluşturulmuştur:

\section{H1: Aşırı iş yükü, işten ayrılma niyetini pozitif ve anlamlı olarak etkilemektedir.}

Aşırı iş yükü, Karasek (1979) tarafından geliştirilen "İş Yükü-Kontrolü Teorisi” ile ilişkilendirilmektedir. Teoriye göre, çalışanın iş yükü ve iş üzerindeki kontrol düzeyi arasındaki ilişki, çalışanların stres düzeyini etkilemektedir (Demiral vd, 2007: 12). Çalışanın işi ile ilgili sahip olduğu bilgi, beceri ve deneyimleri ile bunları işinde kullanabilmesi, iş üzerindeki kontrolünü artırmaktadır. İş üzerindeki kontrol düzeyinin örgüt tarafindan bireye verilen iş yükünün gereklerini yerine getirmesine yardımcı olamaması durumunda, çalışanlar strese girmekte, bu durum ise kaygıyı ortaya çıkarmaktadır (Bolat, 2011: 88).

Genel anlamda kaygı, bireyin çevresel ve psikolojik olaylar karşısında yaşamış olduğu duygu, geleceğe yönelik endişe ve gerginlik hali olarak tanımlanmaktadır (Kaya ve Varol, 2004: 32). Bir başka tanıma göre kaygı, soyut olan bir tehdit veya tehlike karşısında, gelecek odaklı olarak bireyin yaşadığı fiziki, duygusal ve psikolojik etkilenme durumu olarak ifade edilmektedir (Spielberger, 1976). Bireylerde kaygı, durumluk ve sürekli kaygı olarak ikiye ayrılmaktadır. Bireyin istemediği bir durumla karşılaşması ve bu durumun kendisi için tehlikeli olduğunu algılaması durumunda hissettiği durumluk kaygı, somut bir sebep yokken bile bireyin uzun süreli ve şiddetli bir biçimde kaygı yaşaması ise sürekli kaygı olarak tanımlanmaktadır (Spielberger, 1983). Stresin yoğun olarak yaşandığı durumlarda, özellikle aşırı yorgunluk sonucunda, kaygı da yoğun olarak ortaya çıkmaktadır (Norforlk, 1989: 37).

Stresin ortaya çıkmasına, kişisel, örgüt dışı ve örgütsel kaynaklar neden olabilmektedir. Örgütsel stres kaynakları, aşırı iş yükü, rol belirsizliği, kariyer gelişimi, örgüt yapısı gibi nedenlerdir (Kılıç ve Sakallı, 2013: 212). Stres kaynaklarının yoğun olarak hissedilmesi kaygı duygusunu da tetiklemektedir. Yazına bakıldığında, bireylerin strese sebep olabilecek olaylar yaşaması halinde, başa çıkma mekanizmalarının devreye girmemesi durumunda durumsal kaygının, başa çıkma mekanizmalarının yetersiz kalması durumunda sürekli kaygının rol üstlendiği belirtilmiştir (Hovardaoğlu, 1997). Buradan yola çıkarak, aşırı iş yükü gibi örgütsel stres kaynaklarının karşısında çalışanın kendini yetersiz hissetmesi, stres yaşamasına sebep olarak, sürekli kaygı düzeyini etkilediği anlaşılmaktadır. Bu kapsamda yapılan araştırmalara bakıldığında, aşırı iş yükü iş stresinin kaynaklarından birisi olarak sayılmıştır (Pradana ve Salehuddin, 2015). Ahmad ve Saud (2016) tarafindan aşırı iş ve aile rollerinin kaygı düzeyine ve örgütsel vatandaşlık davranışına olan etkisi üzerine yapılan bir araştırmada da, aşırı rol yükünün çalışanların kaygı düzeyini pozitif olarak etkilediği sonucu elde edilmiştir. Role belirsizliği, iş yükü, kişilik ve gerginlik faktörleri arasındaki ilişkiyi açıklamak üzere yapılan bir başka araştırmada ise, niceliksel iş yükü ile gerginlik faktörleri arasında sayılan kaygı arasında pozitif ve anlamlı etki bulunmuştur (Caplan ve Jones, 1975: 717). İş yükü, yönetici desteği, gerginlik ve kaygı, başa çıkma davranışı ilişkisi üzerine yapılan bir başka çalışmada da iş yükü ve gerginlik-kaygı ilişkisi ortaya konulmuştur (Kirmeyer ve Dougherty, 1988: 132). Bu ilişkiler doğrultusunda aşağıdaki hipotez oluşturulmuştur:

H2: Aşırı iş yükü, çalışanların sürekli kaygı düzeyini pozitif ve anlamlı olarak etkilemektedir. 
Tükenme, işten duyulan tatminsizlik, düşük performans ve işten ayrılma gibi olumsuz çıktıların ortaya çıkmasına etki eden durumların başında iş yerinde maruz kalınan stres unsurları gelmektedir (Maslach ve Schaufeli, 1993). İş yerinde yaşanan stresin en önemli kaynağını, iş yükü ve iş yükünden kaynaklanan zaman baskısı oluşturmaktadır (Weiner, 1982: 953). Çalışanların aşırı iş yükü nedeniyle stres yaşaması, işlerini yaparken zevk almamalarına, işyerinde mutlu olamamalarına neden olmakta, bu durumun ise verimlilik ve performansı olumsuz etkileyeceği, işten ayrılmayı isteyebilecekleri değerlendirilmekte, bireyin işyerinden kaynaklı olarak yaşadığı bu durumlarla başa çıkabilmeleri ise, sahip oldukları dayanma gücüne ve kapasitelerine göre değişebildiği belirtilmektedir (Çelik ve Çıra, 2013: 13). Nitekim, Sosyal Araştırmalar Enstitüsü (ISR) Stres Modeli’ne göre çalışma ortamındaki fiziksel (gürültü, 1şık gibi) ve psikolojik (kötü yönetim, rol belirsizliği gibi) kaynaklı stres, çalışanların olumsuz duygular beslemesine neden olabilmektedir (French ve Kahn, 1962; Katz ve Kahn, 1978). Modele göre olumsuz duygular neticesinde, çalışanlar, tükenmişlik, tatminsizlik, performans düşüklüğü, çeşitli hastalıklar, işten ayrılma niyeti, kaygı ve depresyon yaşayabilmektedir (Pyc vd., 2017: 199). İşle ilgili kaygı ve işten ayrılma niyeti üzerine yapılan araştırmalar, çalışanların sahip oldukları kaygı ile işten ayrılma niyeti arasında pozitif ilişki olduğunu ortaya koymaktadır (Byrd vd., 2000; Vanderpool ve Way, 2013). Nitekim, psikolojik sözleşme ihlali, kaygı düzeyi ve işten ayrılma niyeti ilişkisi üzerine spor takımlarının koçlarıyla yapılan bir araştırmada, yüksek düzeyde pozitif yönlü ilişki bulunmuştur (Dhurup vd., 2015). Nissly ve arkadaşları (2005) tarafından yapılan stres, iş-aile çatışması işten ayrılma niyeti üzerine bir diğer araştırmada da, stresin çalışanların kaygı düzeyini artırdığı ve işten ayrılma niyetini pozitif etkilediği belirtilmiştir. $\mathrm{Bu}$ bilgilerden yola çıkılarak şu hipotez oluşturulmuştur:

H3: Çalışanların sürekli kaygl düzeyi, işten ayrllma niyetini pozitif ve anlaml olarak etkilemektedir.

Çalışanların iş yerinde fiziksel ve psikolojik olarak zorlanmaları stres düzeylerini artıran bir durumdur. $\mathrm{Bu}$ durum, işle ilgili olumsuz duyguların, tutumların ve davranışların ortaya çıkmasına neden olmaktadır (Jex, 1998). Yukarıdaki bölümlerde de belirtildiği gibi, yapılan ampirik araştırmalar, stresli bir çalışma ortamı beraberinde kaygı ve depresyonu ortaya çıkarmaktadır (Jensen vd., 2013). Bununla birlikte, çalışanın iş yerinde, psikolojik ve fiziksel olarak zorlanması, işten ayrılma niyetini etkilemektedir. İş Yükü-Kontrolü Teorisine göre (Karasek, 1979), yaşanan stresin en önemli kaynaklarından olan aşırı iş yükünün çalışanların kaygı düzeylerini artıracağı, artan kaygının ise işten ayrılma niyeti gibi olumsuz algıları etkileyeceği belirtilmiştir. Bu teori bağlamında, aşırı iş yükü ve rol belirsizliği gibi sebeplerle, çalışanların iş üzerindeki kişisel kontrollerini zayıflatan taleplerle karşılaşmaları durumunda, sürekli olarak kaygı duyarak, olumsuz durumla başa çıkma mekanizmasının gereğince bu stresli ortamdan uzaklaşmak isteyeceklerdir (De Croon vd., 2004; Jensen vd., 2013). Buradan yola çıkarak, aşırı iş yükünün işten ayrılma niyeti üzerine etkisinde, hissedilen kaygı düzeyinin aracılık edebileceği değerlendirildiğinden aşağıdaki hipotez oluşturulmuştur:

H4: Çalışanların aşırı iş yükü algısının, işten ayrılma niyeti üzerindeki etkisinde sürekli kaygl düzeyinin aracılık rolü vardır.

\section{ARAŞTIRMANIN YÖNTEMI}

Bu bölümde araştırmanın amacı ve modeli, araştırmanın evreni ve örneklemi ile çalışma kapsamında kullanılan ölçekler hakkında bilgi verilecektir. 


\subsection{Araştırmanın Amacı ve Modeli}

$\mathrm{Bu}$ araştırmada güdülen temel amaç, çalışanlarda bulunan sürekli kaygının, işten ayrılma niyeti üzerinde etkisinde aşırı iş yükünün oynadığı rolü tespit etmektir. Bu amaçla oluşturulan çalışma modeli Şekil 1'de gösterilmiştir.

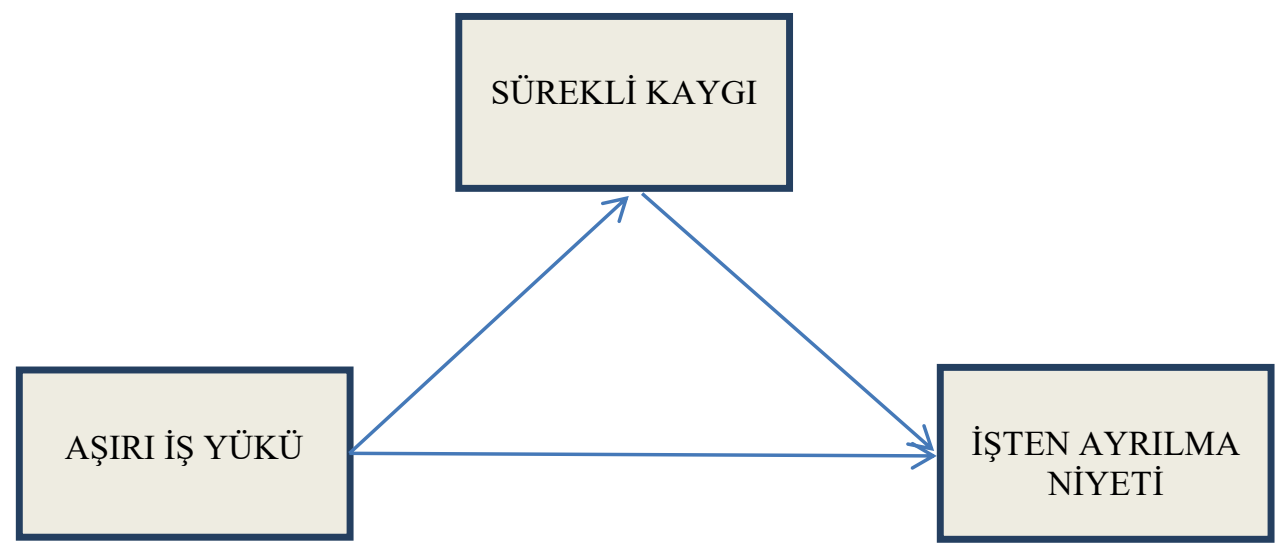

Şekil 1. Araştırma Modeli

Araştırma modeli kapsamında çalışmada, yukarıdaki paragraflarda kurgulanan hipotezlerin test edilmesi amaçlanmıştır.

\subsection{Araştırmanın Evreni ve Örneklemi}

Araştırmanın evrenini, küresel bir sigara firmasının Isparta il genelinde görev yapan saha satış elemanları oluşturmaktadır. Araştırmada öncelikle, sigara firmasının Isparta saha satış sorumlusu ile iletişime geçilerek anket çalışması yapabilmek için gerekli izin alınmıştır. Sonrasında ise kolayda örnekleme metodu kullanılarak toplamda 250 çalışana anket formları dağıtılmış olup 195 anketin geri dönüşü gerçekleşmiştir. Bu kapsamda anket geri dönüş oranı \%78 olarak hesaplanmıştır. Yapılan incelemede 13 anket formunun gelişigüzel doldurulduğu, çok fazla kayıp veri olduğu tespit edilmiş ve bu anket formları çalışmaya dahil edilmemiştir. Sonuçta 182 adet geçerli anket formu üzerinden analizler yapılmıştır. Bryman ve Cramer (2005), kullanılan madde sayısının 5 katı deneğe ulaşılmasının, evreni temsil için yeterli olabileceğini belirtmektedir. Bu doğrultuda araştırmada 34 madde kullanıldığı için ulaşılan örneklem sayısının yeterli olduğu düşünülmektedir.

\subsection{Veri Toplama Tekniği ve Ölçekler}

$\mathrm{Bu}$ çalışmada anket yöntemi kullanılarak veriler toplanmıştır. Anket formu 4 bölümden oluşmakta olup ilk bölümünde katılımcıların demografik niteliklerine yönelik 3 soru yer almaktadır. Anket formunun diğer 3 bölümünde yer alan ölçeklerle ilgili olarak aşağıda ayrıntılı bilgiler verilmektedir.

Araştırmada kullanılan bağımsız değişken olan sürekli kaygıyı ölçmek amacıyla, Spielberger ve arkadaşları (1970) tarafından geliştirilen ve Türkçeye Öner ve Le Compte (1998) tarafından uyarlanan Durumluk ve Sürekli Kaygı Envanteri kullanılmıştır. Bu envanter 2 bölümden oluşmakta olup bu çalışmada sadece sürekli kaygı durumunu ölçmek maksadıyla 
ilgili kısım alınmıştır. Bu kapsamda ölçek 20 madde ve tek boyuttan oluşmaktadır. Ölçek "1: hemen hemen hiçbir zaman" ve "4: hemen hemen her zaman" şeklinde 4'lü Likert tipi derecelendirmeye sahiptir. Ölçekte 7 madde ters puanlanmıştır. Ölçeğin puanlanmasında öncelikle doğrudan ve tersine çevrilmiş maddelerin toplam ağırlıklarının saptanması için iki ayrı anahtar hazırlanır. Doğrudan ifadeler için elde edilen toplam ağırlıklı puandan, ters ifadelerin toplam ağırlıklı puanı çıkartılır ve bu sayıya değişmeyen bir değer eklenir (sürekli kaygı ölçeği için 35). Ölçekten elde edilen toplam puan aralığı 20 ila 80 arasındadır. Puanın artması yüksek kaygıyı, azalması ise düşük kaygıyı belirtir. (Örnek madde: Son zamanlarda kafama takılan konular beni tedirgin ediyor).

Araştırmada işten ayrılma niyeti, Wayne ve arkadaşları (1997) tarafından geliştirilen ve Küçükusta (2007) tarafından Türkçeye uyarlanan 3 maddelik ölçekle ölçülmüştür. Ölçek "1: kesinlikle katılmıyorum" ve "5: kesinlikle katılıyorum" şeklinde 5'li Likert tipi bir derecelendirmeye sahiptir. Küçükusta (2007) ölçeğin Cronbach $\alpha$ iç tutarlılık katsayısını 69 olarak hesaplamıştır. Ölçekte ters puanlanmış madde bulunmamaktadır. (Örnek madde: Sıklıkla bu işten ayrılmayı düşünüyorum).

Saha satış elemanlarının aşırı iş yükü düzeylerini ölçmek amacıyla, Peterson ve arkadaşları (1995) tarafindan geliştirilen ve Derya (2008) tarafindan Türkçeye uyarlanan 11 madde ve tek boyuttan oluşan aşırı iş yükü ölçeği kullanılmıştır. Ölçek " 1 : kesinlikle katılmıyorum" ve "5: kesinlikle katıliyorum" şeklinde 5'li Likert tipi bir derecelendirmeye sahiptir. Ölçekten alınan yüksek puan aşırı iş yükünün varlığına işarettir. Derya (2008), ölçeğin iç tutarlılık katsayısını .86 olarak raporlamıştır. Ölçekte ters puanlanmış 1 ifade bulunmaktadır. (Örnek madde: İş yüküm oldukça ağır).

\subsection{Araştırmada Kullanılan İstatistiksel Yöntemler}

Araştırma verilerinin analizinde SPSS 22 programı kullanılmıştır. Çalışmada ayrıca kullanılan ölçeklerin geçerliliğini test etmek için LISREL 8.80 programından yararlanılmıştır. $\mathrm{Bu}$ kapsamda ölçeklerin geçerliliği doğrulayıcı faktör analizi yardımıyla sınanmıştır. Ölçeklerin güvenilirliğini ölçmek için ise iç tutarlılık katsayısı tercih edilmiştir. Araştırmada kullanılan değişkenlerin aralarındaki ilişkilerin ve etkilerin test edilmesinde korelasyon ve regresyon analizi kullanılmıştır. Sürekli kaygının aracılık rolünü ortaya çıkarabilmek için ise SPSS Process eklentisi kullanılarak regresyon analizi gerçekleştirilmiştir.

\section{BULGULAR}

Araştırma kapsamında elde edilen bulgular, aşağıda başlıklar halinde verilmiştir.

\subsection{Demografik Bulgular}

Araştırmaya katılan saha satış elemanlarının demografik nitelikleri Tablo 1'de verilmektedir. 
Tablo 1. Katılımcılara İlişkin Demografik Veriler

\begin{tabular}{llcc}
\hline & Cinsiyet & Sayı & Yüzde \\
\hline \multirow{2}{*}{ Cinsiyet } & Kadın & 29 & 15.9 \\
& Erkek & 153 & 84.1 \\
\hline \multirow{2}{*}{ Medeni Durum } & Evli & 135 & 74.2 \\
& Bekâr & 47 & 25.8 \\
\hline \multirow{4}{*}{ Eğitim Düzeyi } & İlköğretim & 10 & 5.5 \\
& Lise & 89 & 48.9 \\
& Önlisans & 37 & 20.3 \\
& Lisans & 46 & 25.3 \\
\hline \multirow{3}{*}{ Kıdem } & 3 yıldan az & 49 & 26.9 \\
& 3 - 10 yıl arası & 80 & 44.0 \\
\hline Toplam & 10 yıldan fazla & 53 & 29.1 \\
\hline
\end{tabular}

Tablo 1'de görüldüğü üzere, sektörün yapısında kaynaklı olarak erkek çalışanlar önemli oranda kadın çalışanlara ağır basmaktadır. Evli çalışanların seviyesi bekâr çalışanlara nazaran daha fazladır. Eğitim seviyesi açısından katılımcılar incelendiğinde, ağırlıklı olarak lise mezuniyetine sahip çalışanların varlığı dikkat çekmektedir. Üniversite mezunu çalışan oranı da \%45.6 seviyesinde tespit edilmiştir. Kıdem açısından çalışanlar değerlendirildiğinde ise çoğunluğunun 3 ile 10 yıl arasında kıdemlerinin olduğu görülmüştür. Katılımcıların yaş dağılımları 18 ila 55 arasında değişmektedir. Yaş ortalamaları ise $32.5 \pm 4.41$ olarak tespit edilmiştir.

\section{2. Ölçeklerin Geçerlilik ve Güvenilirlik Analizleri}

$\mathrm{Bu}$ araştırmada kullanılan ölçeklerin yapı geçerliliğini sınamak maksadıyla doğrulayıcı faktör analizinden yararlanılmıştır. Ayrıca ölçeklerin güvenilirliklerini ölçmek amacıyla iç tutarlılık katsayılarına bakılmıştır. Yapı geçerliliğine yönelik elde edilen sonuçlar Tablo 2'de verilmiştir.

Tablo 2. Ölçeklerin Uyum İyiliği Değerleri

\begin{tabular}{lccccccccc}
\hline Değișken & $\#$ & $\chi^{\mathbf{2}} / \mathbf{d f}$ & CFI & NFI & NNFI & GFI & AGFI & SRMR & RMSEA \\
\hline Sürekli Kaygı & 20 & 2.85 & .91 & .92 & .92 & .90 & .87 & .072 & .078 \\
Așırı İş Yükü & 10 & 2.14 & .96 & .93 & .94 & .93 & .90 & .061 & .079 \\
İşten Ayrılma Niyeti & 3 & 2.53 & .98 & .99 & .99 & .94 & .91 & .051 & .065 \\
\hline Kabul Edilebilir Uyum* & & $\leq 5$ & $>.90$ & $>.90$ & $>.90$ & $>.85$ & $>.80$ & $<.08$ & $<.08$ \\
İyi Uyum* & $\leq 3$ & $>.97$ & $>.95$ & $>.97$ & $>.90$ & $>.85$ & $<.05$ & $<.05$ \\
\hline
\end{tabular}

*Joreskog ve Sörbom, (1993); Kline, (1998); Anderson ve Gerbing, (1984).

Tablo 2 ele alındığında, her üç ölçeğinde uyum iyiliği değerlerinin iyi uyum düzeyinde olduğu tespit edilmiştir. Her üç ölçeğinde orijinal çalışmalarda olduğu gibi tek faktörlü yapıları doğrulanmıştır. Aşırı iş yükü ölçeğinde, ters puanlanmış olan 7 numaralı madde, madde faktör yükünün düşük olmasından dolayı ölçekten çıkarılmıştır. Ölçeklerin güvenilirlik analizleri sonuçlarına Tablo 3 'te yer verilmiştir. 
Tablo 3. Ölçeklerin İçsel Tutarılık Katsayıları

\begin{tabular}{lcc}
\hline Değişken & Madde Sayısı & $\boldsymbol{\alpha}$ \\
\hline Sürekli Kaygı & 20 & .85 \\
Aşırı İş Yükü & 10 & .81 \\
İşten Ayrılma Niyeti & 3 & .80 \\
\hline
\end{tabular}

Tablo 3'te sonuçlara bakıldığında, iç tutarlılık katsayılarının yazında genel kabul gören .70'in üzerinde olduğu tespit edilmiştir. Bu sonuca göre, kullanılan 3 ölçüm aracının da yüksek seviyede güvenilir oldukları değerlendirilmiştir (Nunnally, 1978).madde

\subsection{Değişkenler Arası İlişkilere İlişkin Bulgular}

Değişkenler arasındaki ilişkiler Pearson korelasyon analizi yardımıyla tespit edilmeye çalışılmıştır. Bu kapsamda hazırlanan Tablo 4'te ayrıca değişkenlere ait aritmetik ortalama, standart sapma ve çarpıklık/basıklık değerleri de verilmiştir.

Tablo 4. Betimsel İstatistikler ve Değişkenler Arası İlișkiler

\begin{tabular}{lccccccc}
\hline Değişkenler (n=182) & Ort. & SS & Çarpıklık & Basıklık & $\mathbf{1}$ & $\mathbf{2}$ & $\mathbf{3}$ \\
\hline 1. Aşırı İş Yüküi & 2.36 & .723 & .615 & .065 & 1 & & \\
2. Sürekli Kaygı & 43.35 & 6.397 & .386 & .281 & $.234^{* *}$ & 1 & \\
3. İşten Ayrılma Niyeti & 1.80 & .887 & .877 & -.326 & $.173^{*}$ & $.447^{* *}$ & 1 \\
\hline
\end{tabular}

$* p<.05, * * p<.01$.

Tablo 4 incelendiğinde, değişkenlere ait çarpıklık ve basıklık katsayılarının \pm 1 aralığında olduğu görülmektedir. Verilerin normal dağılım gösterdiğinin kabulü için çarpıklık ve basıklık katsayıların \pm 1 aralığında olması gerektiği ileri sürülmüştür (Morgan vd. 2004: 49). Elde edilen bu sonuçtan yola çıkılarak araştırmada parametrik analiz teknikleri kullanılmıştır.

Tablo 4'ten görülebileceği üzere, katılımcılar çok düşük düzeyde işten ayrılma niyeti taşımaktadırlar (1.80土.887). Aynı zamanda katılımcıların algıladıkları iş yükü seviyeleri orta nokta olan 3 değerinin bir hayli altındadır (2.36 .723). Bu doğrultuda saha satış elemanlarının iş yükü seviyelerinin aşırı olmadığı, hatta düşük sayılabilecek bir seviyede olduğu tespit edilmiştir. Çalışanların sürekli kaygı seviyesi ise $(43.35 \pm 6.397)$ ortalama bir değer olarak düşünülmektedir. Daha öncede söylendiği gibi sürekli kaygı puanları 20 ila 80 aralığında değerler almaktadır. Bu kapsamda saha satış elemanlarının elde ettikleri puan ortalaması yüksek bir kaygı seviyesini işaret etmemektedir.

Tablo 4'deki korelasyon analizi sonuçları incelendiğinde, tüm değişkenler arasında anlamlı ilişkiler olduğu görülmektedir. Buna göre sürekli kaygı ile işten ayrılma niyeti $(\mathrm{r}=.447, \mathrm{p}<$ $.01)$ ve aşırı iş yükü arasında $(\mathrm{r}=.234, \mathrm{p}<.01)$ pozitif yönlü anlamlı ilişkiler söz konusudur. Yine Tablo 3'den görüleceği üzere aşırı iş yükü ile işten ayrılma niyeti arasında da ( $\mathrm{r}=.173$, $\mathrm{p}<.05)$ pozitif yönlü anlamlı bir ilişki tespit edilmiştir.

\subsection{Hipotez Testine İlişkin Bulgular}

Araştırmanın 1 ve 3 numaralı hipotezleri basit regresyon analizi yardımıyla sınanmıştır. Bu kapsamda analiz sonuçlarına göre, aşırı iş yükünün işten ayrılma niyeti üzerine pozitif yönlü 
anlamlı etkisi $(b=.024, p<.05)$ tespit edilmiştir. Buna göre aşırı iş yükü işten ayrılma niyetini \%3 düzeyinde açıklamaktadır. Yine analiz sonuçlarına göre sürekli kaygının, işten ayrılma niyeti üzerine pozitif yönlü anlamlı etkisi $(b=.595, \mathrm{p}<.001)$ görülmüştür. Sürekli kaygı işten ayrılma niyetini \%20 seviyesinde açıklamaktadır. Bu sonuçlar uyarınca araştırmanın 1 ve 3 numaralı hipotezleri kabul edilmiştir.

Araştırmada, sürekli kaygı ile işten ayrılma niyeti arasındaki ilişkide, aşırı iş yükü algısının aracılık rolünü tespit etmek amacıyla, Bootstrap yöntemiyle regresyon analizi gerçekleştirilmiştir. Aracılık modellerinin analizinde, Baron ve Kenny (1986)'nin geleneksel yaklaşımı yazında çok sık bir şekilde kullanılmaktadır. Buna karşın özellikle son zamanlarda, aracılık modellerinin analizi için daha sağlıklı sonuçlara imkân tanıyan modern yaklaşım (Bootstrap) öne sürülmüştür. Modern yaklaşım; Baron ve Kenny'nin yaklaşımından farklı olarak, birbiri ardına sıralanan adımlara ilişkin koşulların yerine getirilmesini gerekli görmemekte, bu koşullar gerçekleşmese dahi aracılık etkisinden (dolaylı etkiden) bahsedilebileceğini öngörmektedir. Yani dolaylı etkinin anlamlı olması durumu, aracılık modelinin kabul edilmesi için yeterli görülmektedir. Buna göre, dolaylı etki değerine tekabül eden alt ve üst güven aralığı değerleri sıfır değerini kapsamıyor ise dolaylı etki anlamlı olarak kabul edilmekte ve aracılık etkisinin meydana geldiği anlaşılmaktadır (Gürbüz ve Bayık, 2018). Bootstrap regresyon analizi, SPSS Process eklentisi aracılığıyla gerçekleştirilmiştir. Analizde 4. model seçilerek aracılık etkisi ortaya çıkarılmaya çalışılmıştır. Bootstrap regresyon analizi sonuçları Tablo 5'te gösterilmiştir.

Tablo 5. Bootstrap Regresyon Analizi Sonuçları

\begin{tabular}{lcccccc}
\hline \multirow{2}{*}{ Değişkenler } & \multicolumn{3}{c}{ Sürekli Kaygı } & \multicolumn{3}{c}{ İşten Ayrılma Niyeti } \\
\cline { 2 - 7 } & $b$ & $L L C I$ & $U L C I$ & $b$ & $L L C I$ & $U L C I$ \\
\hline Aşırı İş Yükü & $.025^{* *}$ & .0095 & .0394 & .010 & -.009 & .029 \\
Sürekli Kaygı (Aracı) & & & & $.572^{* * *}$ & .392 & .753 \\
$\mathrm{R}^{2}$ & & & & & .205 & \\
\cline { 2 - 6 }
\end{tabular}

Bootstrap Dolaylı Etki

Aşırı İş Yükü $\rightarrow$ Sürekli Kaygı $\rightarrow$ İşten Ayrılma Niyeti

$b=.014,95 \%$ BCA CI $[.0051, .0258]$

$* * p<.01,{ }^{* * *} p<.001 ;$ S.H.: Standart Hata. Standardize edilmemiş beta (b) katsayıları raporlanmıştır.

Tablo 5 incelendiğinde, aşırı iş yükünün sürekli kaygı üzerine pozitif yönlü anlamlı etkisi ( $b=$ $.025, \mathrm{p}<.01)$ bulunmuştur. Bu kapsamda araştırmanın 2 numaralı hipotezi kabul edilmiştir. Aracılık etkisine yönelik sonuçlara göre, sürekli kaygının aşırı iş yükü vasıtasıyla işten ayrılma niyeti üzerindeki dolaylı etkisinin anlamlı olduğu $(b=.014,95 \%$ BCA CI $[.005, .026)$ görülmüş olup 4 numaralı hipotez de kabul edilmiştir.

\section{SONUÇ ve TARTIŞMA}

$\mathrm{Bu}$ çalışmanın temel amacı, çalışanların aşırı iş yükü algısının işten ayrılma niyetlerini nasıl etkilediğini ortaya koymak ve bu ilişkide sürekli kaygı düzeyinin oynadığı rolü belirlemektir. Araştırma sonuçlarına göre, aşırı iş yükünün, işten ayrılma niyeti üzerinde pozitif ve anlamlı bir etkiye sahip olduğu anlaşılmıştır. Elde edilen bu bulgu ile Iverson ve Deery (1997), Sümer ve Van de Ven (2007), Zeytinoğlu ve arkadaşları (2007), Lee (2011), Qureshi ve arkadaşları (2013), Duxbury ve Halinski (2014), Altay ve Turunç (2018) tarafindan yapılan araştırma sonuçlarının uyumlu olduğu görülmektedir. 
Araştırma sonuçlarından elde edilen bir diğer bulgu ise, aşırı iş yükünün, çalışanların kaygı düzeyini etkilediğidir. Ayrıca çalışanların kaygı düzeyinin, işten ayrılma niyetini anlamlı bir şekilde etkilediği de bulunmuştur. Bu sonuçlar ile önceki araştırmaların sonuçları paralellik göstermektedir. Nitekim, Caplan ve Jones (1975), Kirmeyer ve Dougherty (1988), Pradana ve Salehuddin (2015), Ahmad ve Saud (2016) tarafından yapılan araştırmalarda da belirtildiği gibi, çalışanların niteliksel ve niceliksel olarak kendilerine yüklenen işin aşırı olduğunu algılamaları, işi istenen şekilde veya zamanında bitirememesi, sahip olduğu niteliklerin işi başarmalarına yetememesi gibi durumlar strese ve gerginliğe girmelerine neden olarak kaygı düzeylerinin artmasına sebep olmakta, bu ise olumsuz durum ve koşullardan uzaklaşmak istemelerine neden olmaktadır. Bu istek sonucunda doğal olarak, işten ayrılma niyeti veya davranışı ortaya çıkmaktadır.

Araştırma neticesinde, kaygı düzeyinin aşırı iş yükü ve işten ayrılma niyeti ilişkisinde aracılık rolünün olduğunun ortaya konulmasının, yazına önemli bir katkı sağladığ1 değerlendirilmektedir. Özellikle yerli yazında, iş yükü - işten ayrılma niyeti ilişkisinde, çalışanların kaygı düzeyinin rolüne ilişkin bir araştırmaya rastlanmamıştır. Uluslararası yazında ise, kaygının aracılık rolü olduğuna ilişkin bulgulara rastlamak mümkünse de, söz konusu aracılık etkisi, liderlik, tükenmişlik, iş tatmini gibi başka değişkenler arasındaki ilişkide ele alınmıştır. Ampirik çalışmalarda, araştırmanın değişkenleri olan aşırı iş yükü, işten ayrılma niyeti, kaygı arasındaki ilişkiyi birlikte ortaya koyan çalışmaya rastlanılmasa da, Karaser (1979) tarafindan geliştirilen İş Yükü-Kontrolü Teorisi'nin varsayımlarını doğrular nitelikte sonuçlar elde edilmiştir.

Elde edilen bu sonuçlar ışığında, uygulayıcılar tarafından iş yerinde stres kaynağı olarak değerlendirilen kişilik özelliklerinin, örgütsel ve çevresel faktörlerin olumsuz etkilerinin azaltılmasına ilişkin önlemler alınması gerekmektedir. Özellikle çalışana, üstesinden gelemeyeceği sayıda veya özellikte iş verilmesinin önüne geçecek bir yönetim anlayışının ve örgütsel politikaların uygulanması gerekmektedir. Bununla birlikte, çalışanların üstlendikleri iş yükünün dengeli, adil ve iş gerekleri ile çalışan nitelikleri dikkate alınarak dağıtılması gerekmektedir. Ayrıca, çalışanın kaygıdan uzaklaşmasını ve işgücü devir oranının azaltılmasını sağlayacak performans değerlendirme, iş değerleme, ücret ve ödül yönetimi ile ilgili İK politikaları oluşturulmalı, çalışanların niteliksel olarak aşırı iş yükü algısının azaltılması amacıyla, kendisine yüklenen işin gerektirdiği bilgi, beceri ve deneyimi kazanmaları hedeflenerek, eğitim ve geliştirme çalışmaları yapılmalıdır.

Araştırmada bir takım kısıtlar da söz konusudur. Bunlardan ilki, sadece bir sektörden ve sınırlı sayıda personelle araştırmanın yapılmasıdır. Bir diğer kısıt ise, çalışanların sosyal beğenirlik düzeyinin araştırmaya dahil edilmemesi, öz-değerlendirmeye dayalı olarak verilerin toplanması ve araştırma deseninin kesitsel tarzda oluşturulmasıdır. Bu durumun, ortak yöntem yanlılığına sebep olabileceği değerlendirilmektedir. Tüm bu önerilerle birlikte, araştırma sonuçlarının genelleştirilebilmesi için, farklı sektörlerden farklı örneklemler üzerinde araştırmanın tekrarlanmasında fayda görülmektedir. Bununla birlikte, aşırı iş yükü ile performans, iş tatmini, örgütsel bağlılık arasındaki ilişkilerin araştırılması, yaş ve kıdem gibi değişkenlerin rolünün açığa çıkarılması, gelecekte yapılacak araştırmalar için önerilmektedir. 


\section{KAYNAKÇA}

--- (2013). "Understanding Ergonomics at Work". Health and Safety Executive Publication, Free Leaflets. http://www.hse.gov.uk/pubns/indg90.pdf; Erişim Tarihi: 10.04.2018.

AHMAD, A., \& SAUD, S. (2016). "The Effect of Role Overload on Employee Anxiety and Organization Citizenship Behavior”. Journal of Managerial Sciences, 10(1): 45-54.

AIKEN Jr, L. R. (1976). "Update on Attitudes and Other Affective Variables in Learning Mathematics". Review of Educational Research, 46(2): 293-311.

AJZEN, I., \& FISHBEIN, M. (1980). Understanding Attitudes and Predicting Behavior. Englewood Cliffs, NJ: Prentice Hall.

AKDENİ, M. O. (2018). Örgütsel Sessizliğin İşten Ayrılma Niyeti Üzerine Etkisi ve İşletmelerde Bir Uygulama. Yayınlanmamış Yüksek Lisans Tezi, Sivas Cumhuriyet Üniversitesi Sosyal Bilimler Enstitüsü, Sivas.

ALTAY, M., \& TURUNÇ, Ö. (2018). "İş Yükü, Çalışma Yaşam Kalitesi ve İşten Ayrılma Niyeti İlişkisi: Lider-Üye Etkileşiminin ve Örgütsel Bağlılığın Aracılık Rolü’. Kafkas Üniversitesi İktisadi ve İdari Bilimler Fakültesi Dergisi, 9(17): 191-229.

ANDERSON, J. C., \& GERBING, D. W. (1984). "The Effect of Sampling Error on Convergence, Improper Solutions, and Goodness-Of-Fit Indices for Maximum Likelihood Confirmatory Factor Analysis”. Psychometrika, 49(2): 155-173.

AYCAN, Z., ESKİN, M., \& YAVUZ, S. (2007). Hayat Dengesi: İş, Aile ve Özel Hayatı Dengeleme Sanatı. İstanbul: Sistem Yayıncılı.

BARON, R. M., \& KENNY, D. A. (1986). “The Moderator-Mediator Variable Distinction in Social Psychological Research: Conceptual, Strategic, and Statistical Considerations". Journal of Personality and Social Psychology, 51(6): 1173-1182.

BOLAT, O. (2011). “İş Yükü, İş Kontrolü ve Tükenmişlik İlişkisi”. Atatürk Üniversitesi İktisadi ve İdari Bilimler Dergisi, 25(2): 87-101.

BRYMAN, A., \& CRAMER, D. (2005). Quantitative Data Analysis with SPSS 12 and 13: A Guide for Social Scientists. New York: Routledge. Taylor \& Francis Group.

BYRD, T. G., COCHRAN, J. K., SILVERMAN, I. J., \& BLOUNT, W. R. (2000). “Behind Bars: An Assessment of the Effects of Job Satisfaction, Job-Related Stress, and Anxiety on Jail Employees' Inclinations to Quit”, Journal of Crime and Justice, 23(2): 69-93.

CAPLAN, R. D., \& JONES, K. W. (1975). "Effects of Work Load, Role Ambiguity, and Type a Personality on Anxiety, Depression, and Heart Rate", Journal of Applied Psychology, 60(6): 713-719.

DE CROON, E. M., SLUITER, J. K., BLONK, R. W., BROERSEN, J. P., \& FRINGSDRESEN, M. H. (2004). "Stressful Work, Psychological Job Strain, and Turnover: A 2-Year Prospective Cohort Study of Truck Drivers". Journal of Applied Psychology, $89(3), 442$. 
DEMIRAL, Y., ÜNAL, B., KILIÇ, B., SOYSAL, A., BİlgiN, A. C., UÇKU, R., \& THEORELL, T. (2007). "İş Stresi Ölçeğinin İzmir Konak Belediyesi'nde Çalışan Erkek İşçilerde Geçerlik ve Güvenilirliğinin İncelenmesi”. Toplum Hekimliği Bülteni, 26(1), 11-18.

DERYA, S. (2008). Crossover of Work-Family Conflict: Antecedent and Consequences of Crossover Process in Dual-Earner Couples. Yayımlanmamış Doktora Tezi, Koç Üniversitesi Sosyal Bilimler Enstitüsü, İstanbul.

DHURUP, M., KEYSER, E., \& SURUJLAL, J. (2015). "The Psychological Contract, Violation of the Psychological Contract, Work-Related Anxiety and Intention to Quit of Sport Coaches in South Africa". African Journal for Physical Health Education, Recreation and Dance, 21(Supplement 1), 195-208.

DUXBURY, L., \& HALINSKI, M. (2014). "Dealing with the "Grumpy Boomers": ReEngaging the Disengaged and Retaining Talent". Journal of Organizational Change Management, 27(4), 660-676.

FRENCH, J. R. P., Jr., \& KAHN, R. L. (1962). "Work, Health and Satisfaction”, Journal of Social Issues, 18(3), 1- 47.

GÖKKAYA, Ö. (2014). "Yerel Yönetimlerde İş-Yaşam Dengesi ve Çalışan Davranışı İlişkisinin İncelenmesi: Kocaeli Belediyeleri Örneği”. Elektronik Mesleki Gelişim ve Araştırmalar Dergisi, 2, 1-18.

GÜMÜŞTEKIN, G. E., \& ÖZTEMIZ, A. B. (2005). "Örgütlerde Stresin Verimlilik ve Performansla Etkileşimi”. Çukurova Üniversitesi Sosyal Bilimler Enstitüsü Dergisi, 14(1), 271-288.

GÜRBÜZ, S., \& BAYIK, M. E. (2018). "Arac1lkk Modellerinin Analizinde Modern Yaklaşım: Baron ve Kenny Yöntemi Artık Terk Edilmeli Mi?”. 6. Örgütsel Davranış Bildiri Kitab1, 30-45.

HETTY VAN EMMERIK, I. J., BAKKER, A. B., \& EUWEMA, M. C. (2009). "Explaining Employees' Evaluations of Organizational Change with the Job-Demands Resources Model". Career Development International, 14(6), 594-613.

HOVARDAOĞLU, S. (1997). "Stres Belirtileri İle Durumsal ve Sürekli Kaygının Yordanması". Kriz Dergisi, 5(2), 127-134.

ILIES, R., DIMOTAKIS, N., \& DE PATER, I. E. (2010). "Psychological and Physiological Reactions to High Workloads: Implications for Well-Being”. Personnel Psychology, 63(2), 407-436.

IVERSON, R. D., \& DEERY, M. (1997). "Turnover Culture in the Hospitality Industry". Human Resource Management Journal, 7(4), 71-82.

JACOBS, E. J., \& ROODT, G. (2011). "The Mediating Effect of Knowledge Sharing Between Organisational Culture and Turnover Intentions of Professional Nurses". South African Journal of Information Management, 13(1), 1-6. 
JENSEN, J. M., PATEL, P. C., \& MESSERSMITH, J. G. (2013). High-Performance Work Systems and Job Control: Consequences for Anxiety, Role Overload, and Turnover Intentions. Journal of Management, 39(6), 1699-1724.

JEX, S. M. (1998). Stress and Job Performance: Theory, Research, and Implications for Managerial Practice. Thousand Oaks, CA: Sage.

JONES, E., ROBERTS, J. A., \& CHONKO, L. B. (2000). "Motivating Sales Entrepreneurs to Change: A Conceptual Framework of Factors Leading to Successful Change Management Initiatives in Sales Organizations". Journal of Marketing Theory and Practice, 8(2), 37-49.

JORESKOG, K., \& SORBOM, D. (1993). LISREL 8: Structural Equation Modeling with the Simplis Command Language. Chicago, IL: Scientific Software International Inc.

KARASEK Jr, R. A. (1979). Job Demands, Job Decision Latitude, and Mental Strain: Implications for Job Redesign. Administrative Science Quarterly, 24, 285-308.

KATZ, D., \& KAHN, R. L. (1978). The Social Psychology of Organizations (2nd ed.). New York, NY: Wiley.

KAYA, M. A., \& VAROL, K. (2004). “İlahiyat Fakültesi Öğrencilerinin Durumluk-Sürekli Kaygı Düzeyleri ve Kaygı Nedenleri (Samsun Örneği)”. Ondokuz Mayıs Üniversitesi İlahiyat Fakültesi Dergisi, 17(17), 31-63.

KILIÇ, R., \& ÖZAFŞARLIOĞLU SAKALLI, S. (2013). "Örgütlerde Stres Kaynaklarının Çalışanların İş-Aile Çatışması Üzerine Etkisi”. Uşak Üniversitesi Sosyal Bilimler Dergisi, 6(3), 208-237.

KIRMEYER, S. L., \& DOUGHERTY, T. W. (1988). "Work Load, Tension, and Coping: Moderating Effects of Supervisor Support”. Personnel Psychology, 41(1), 125-139.

KLINE, R. B. (1998). Principles and Practice of Structural Equation Modeling. New York: Guilford Press.

KORKMAZ, Z. (2012). Yeni Doğan Hemşirelerinde İş Analizi ve İş Yükü. Yayınlanmamış Doktora Tezi, Erciyes Üniversitesi Sağlık Bilimleri Enstütüsü, Kayseri.

KÜÇÜKUSTA, D. (2007). Konaklama İşletmelerinde İş-Yaşam Dengesinin Çalışma Yaşamı Kalitesi Üzerindeki Etkisi. Yayınlanmamış Doktora Tezi, Dokuz Eylül Üniversitesi Sosyal Bilimler Enstitüsü, İzmir.

LAI, S. L., CHANG, J., \& HSU, L. Y. (2012). "Does Effect of Workload on Quality of Work Life Vary With Generations?”. Asia Pacific Management Review, 17(4), 437-451.

MASLACH, C., \& SCHAUFELI, W. B. (1993). "Historical and Conceptual Development of Burnout". İçinde W. B. Schaufeli, C. Maslach, \& T. Marek (Eds.), Professional Burnout: Recent Developments in Theory and Research (ss. 1-16). Washington, DC: Taylor \& Francis.

MORGAN, G. A., LEECH, N. L., GLOECKNER, G. W., \& BARRET, K. C. (2004). SPSS for Introductory Statistics: Use and Interpretation. Second Edition. London: Lawrance Erlbaum Associates. 
NISSLY, J. A., BARAK, M. E. M., \& LEVIN, A. (2005). "Stress, Social Support, and Workers' Intentions to Leave Their Jobs in Public Child Welfare". Administration in Social Work, 29(1), 79-100.

NORFORLK, D. (1989). İş Hayatında Stres Kaynakları, Leyla Serdaroğlu (çev.), İstanbul: Form Yayınları.

NUNNALLY, J. C. (1978). Psychometric Theory. New York: McGraw-Hill.

OCAKTAN, M. E., KEKLİK, A., \& ÇÖL, M. (2002). “Abidinpaşa Sağlık Ocağında Çalışan Sağlık Personelinde Spielberg Durumluk ve Sürekli Kaygı Düzeyleri”. Ankara Üniversitesi Tıp Fakültesi Dergisi, 55(1), 21-28.

ÖNER, N., \& LE COMPTE, A. (1998). Süreksiz Durumluk/Sürekli Kayg1 Envanteri El Kitabı. İstanbul: Boğaziçi Üniversitesi Yayınevi.

ÖZKALP, E., \& KIREL, Ç. (2005). Örgütsel Davranış, Eskişehir: Anadolu Üniversitesi Yayınlar1.

PETERSON, M. F., SMITH, P. B, AKANDE, A., AYESTARAN, S., BOCHNER, S., CALLAN, V., .... VIEDGE, C. (1995). "Role Conflict, Ambiguity, and Overload: A 21-Nation Study". The Academy of Management Journal, 38(2), 429-452.

PORTOGHESE, I., GAlletTA, M., BATTistelli, A., \& LEITER, M. P. (2015). “A Multilevel Investigation on Nursing Turnover Intention: The Cross-Level Role of Leader-Member Exchange”. Journal of Nursing Management, 23(6), 754-764.

PRADANA, A., \& SALEHUDIN, I. (2015). "Work Overload and Turnover Intention of Junior Auditors in Greater Jakarta, Indonesia". The South East Asian Journal of Management, 9(2), 108-124.

PYC, L. S., MELTZER, D. P., \& LIU, C. (2017). “Ineffective Leadership and Employees' Negative Outcomes: The Mediating Effect of Anxiety and Depression”. International Journal of Stress Management, 24(2), 196-215.

QURESHI, M. I., IFTIKHAR, M., ABBAS, S. G., HASSAN, U., KHAN, K., \& ZAMAN, K. (2013). "Relationship Between Job Stress, Workload, Environment and Employees Turnover Intentions: What We Know, What Should We Know". World Applied Sciences Journal, 23(6), 764-770.

RUSBUlt, C. E., FARRELL, D., ROGERS, G., \& MAINOUS III, A. G. (1988). "Impact of Exchange Variables on Exit, Voice, Loyalty, and Neglect: An Integrative Model of Responses to Declining Job Satisfaction”. Academy of Management Journal, 31(3), 599-627.

SPIELBERGER, C. D. (1983). Manual for the State-Trait Anxiety Inventory. Consulting Psychologists Press, Palo Alto, California.

SPIELBERGER, C. D., GORSUCH, R. L., \& LUSHENE, R. E. (1970). Manual for the StateTrait Anxiety Inventory. Palo Alto, CA: Consulting Psychologists Press. 
SÜMER, H., \& VAN DEN VEN, C. (2008). A Proposed Model of Military Turnover. Technical Report. NATO Research and Technology Organization (Reference Number: RTOTR-HFM-107).

SWARTZ, D. B. (1999). Job Satisfaction of Interpreters for the Deaf. Yayınlanmamış Doktora Tezi, Capella University, Minneapolis.

TETT, R. P., \& MEYER, J. P. (1993). "Job Satisfaction, Organizational Commitment, Turnover Intention, and Turnover: Path Analyses Based on Meta-Analytic Findings". Personnel Psychology, 46(2), 259-293.

VANDERPOOL, C., \& WAY, S. A. (2013). "Investigating Work-Family Balance, Job Anxiety, and Turnover Intentions as Predictors of Health Care and Senior Services Customer-Contact Employee Voluntary Turnover". Cornell Hospitality Quarterly, 54(2), 149-160.

WAYNE, S. J., SHORE, L. M., \& LIDEN, R. C. (1997). "Perceived Organizational Support and Leader-Member Exchange: A Social Exchange Perspective". The Academy of Management Journal, 40(1), 82-111.

WEINER, J. S. (1982). “The Measurement of Human Workload”. Ergonomics, 25(11), 953 965.

YILDIRIM, D., \& AYCAN, Z. (2008). 'Nurses' Work Demands and Work-Family Conflict: A Questionnaire Survey”. International Journal of Nursing Studies, 45(9), 1366-1378.

YILDIZ, B. (2016). “Madolyonun Öteki Yüzü: Zorunlu Vatandaşlık Davranışı”. Eurasian Academy of Sciences Eurasian Business \& Economics Journal, 2(2), 88-99.

ZEYTINOGLU, I. U., DENTON, M., DAVIES, S., BAUMANN, A., BLYTHE, J., \& BOOS, L. (2007). "Deteriorated External Work Environment, Heavy Workload and Nurses' Job Satisfaction and Turnover Intention”. Canadian Public Policy, 33(1), 31-47. 